\title{
Cleaning the Apical Third of Curved Canals After Different Irrigation Protocols
}

\author{
Érika Sales Joviano PEREIRA ${ }^{1}$ \\ Isabella Faria da Cunha PEIXOTO ${ }^{1}$ \\ Rodrigo Keigo Lopes NAKAGAWA ${ }^{1}$ \\ Vicente Tadeu Lopes BUONO ${ }^{2}$ \\ Maria Guiomar de Azevedo BAHIA ${ }^{1}$
}

${ }^{1}$ Department of Restorative Dentistry, School of Dentistry, UFMG - Federal University of Minas Gerais, Belo Horizonte, MG, Brazil

${ }^{2}$ Department of Metallurgical and Materials Engineering, Engineering School, UFMG - Federal University of Minas Gerais, Belo Horizonte, MG, Brazil

\begin{abstract}
This study evaluated the protocols of sonic and vacuum irrigation regarding the capacity of debris removal from root canal systems. Canal preparations were carried out on 30 mandibular first molars using the ProTaper Universal System. Teeth were divided into two experimental groups $(n=15)$ : Group 1: sonic irrigation and Group 2: vacuum irrigation protocol. Subsequently, the mesial roots were sectioned and observed by stereomicroscopy and scanning electron microscopy. Three independent examiners evaluated images of the apical thirds according to the following scores: $1=$ small presence of debris, $2=$ moderate presence of debris, and $3=$ dense presence of debris. Data were analyzed with ANOVA and Kruskal-Wallis tests $(\alpha=0.05)$. Comparison among the groups revealed that at the apical third, the root halves of Group 1 had significantly less surface debris $(\mathrm{p}=0.002)$ than those of Group 2. However, at $2 \mathrm{~mm}$ from the working length, Group 2's specimens showed less remaining debris in approximately $75 \%$ of the analyzed root canals. At the whole apical third, the sonic irrigation protocol removed significantly more debris than the vacuum protocol. However, in the region at 2 $\mathrm{mm}$ from the working length, the second irrigation method demonstrated a better performance.
\end{abstract}

Key Words: endodontics, root canal therapy, irrigation.

\section{INTRODUCTION}

Chemomechanical preparation of the root canal system (RCS) is geared toward the elimination of remnants of pulp tissues, microorganisms, antigenic products, and debris (1). A variety of chemical agents have been used during instrumentation as irrigating agents, with sodium hypochlorite $(\mathrm{NaOCl})$ being the most commonly used among them due to its antimicrobial property and proteolytic activity (1-3). A solution of $17 \%$ Ethylenediaminetetraacetic acid (EDTA) is another irrigating agent frequently employed due to its chelating effect, i.e., it eliminates calcium ions from the inorganic component of dentine and is used to remove the smear layer created during root canal preparation (4).

At the apical third, cleanliness is critical due to the limited space, low permeability (5) and complex anatomical configuration (6). Conventional irrigation methods are known to be effective at cleaning root canals coronally, but less effective apically (7). To obtain optimal results, an irrigation method must also be effective at the working length (WL). Passive irrigation, which begins by slowly injecting an irrigant into the canal through a variety of different gauged and flexible cannulas, presents limitations due to the inability of the irrigant to reach the WL and exchange fluids in this area $(4,8,9)$.

Currently, emphasis has been devoted to hydrodynamic disinfection, consisting of sonic or ultrasonic fluid activation in well-shaped canals in such a way that fluid vibration generates shear stresses capable of disrupting biological cells and removing debris (10-12). Another manner to promote fluid

Correspondence: Prof. Vicente T. L. Buono, Departamento de Engenharia Metalúrgica e de Materiais, Universidade Federal de Minas Gerais, Av. Antonio Carlos, 6627, 31270-901 Belo Horizonte, MG, Brasil. Tel: +55-31-3409-1859. Fax: +55-31-3409-1815. e-mail: vbuono@demet.ufmg.br 
circulation is through pressure alternation, which pulls the irrigant from a fresh supply into the chamber, down the canal to the tip of a cannula, ultimately developing a current inside the RCS (13). The first experimental use of this mechanism was called "noninstrumentation technology" (14), where $\mathrm{NaOCl}$ was introduced into and removed from the canal by the use of alternating sub-ambient pressure fields. However, this technique was not considered safe for in vivo animal studies and therefore was not transferred to human clinical trials (15). Several emerging methods, which include manual agitation, the use of brushes, ultrasonic irrigation, sonic irrigation, and vacuum irrigation, are currently being explored (16).

A number of authors have investigated active irrigation methods $(8,15,17,18)$, but further investigation is required concerning debris removal. The purpose of the present study was to assess the cleanliness of the dentin walls on the apical third of molar root canals after application of two irrigation protocols: sonic and vacuum irrigation.

\section{MATERIAL AND METHODS}

Upon approval by the Ethics Committee from the Federal University of Minas Gerais, Brazil (reference number ETIC, CAAE - 040.0.203.000-08), 30 extracted mandibular first molars were selected for this study. Only mesial canals with separated apical foramina were analyzed. Initially, the canals were explored using \#10 and \#15 stainless steel K-files (Dentsply Maillefer, Ballaigues, Switzerland) up to the length where the instrument was just visible at the foramen. The working length (WL) was established at a point $0.5 \mathrm{~mm}$ short of this length. The canal radius and angle of curvature were determined as defined by Pruett et al. (19), by analyzing orthograde and angled radiographs projected at $\times 10$ magnification in a profile projector (Mitutoyo, Tokyo, Japan). Before instrumentation, two parallel longitudinal grooves were made on the buccal and lingual surfaces of the roots with a flexible diamond disc (KG Sorensen, São Paulo, SP, Brazil). To prevent over-irrigation, teeth were stabilized on a silicone putty base (Silon 2APS Dense; Dentsply Maillefer).

The cleaning and shaping of the root canals in both groups were performed using Gates Glidden drills, in the sequence of 4, 3, and 2, followed by the ProTaper Universal instruments (PTU) (Dentsply Maillefer) according to a crown-down technique. S1, S2, and SX
PTU instruments were used to shape the coronal thirds. The apical third was prepared with S1, S2, F1, and F2 PTU instruments up to the WL (20). The canal and pulp chamber were maintained full of irrigant throughout these procedures.

Teeth were randomly divided into 2 groups of 15 teeth each and prepared following the procedures summarized in Figure 1. These procedures, which follow strictly the manufacturer's of the EndoActivator and EndoVac systems $(6,13)$, can be described as follows: Group 1: this group used the EndoActivator System (Advanced Endodontics, Santa Barbara, CA, USA), consisting of a hand piece and three polymer tips which closely correspond to file nomenclature sizes $15 / .02$, 25/.04 and 35/.04. After cleaning and shaping, the canals received active sonic irrigation through the red tip $(25 / .04)$ as indicated by Ruddle (6). The tip, positioned $2 \mathrm{~mm}$ short from the WL, was activated at 10,000 cycles per min for $60 \mathrm{~s}$ in each canal, with the canal and pulp chamber filled with $1.0 \mathrm{~mL}$ of $5.25 \% \mathrm{NaOCl}$. The canal was then rinsed with $1.0 \mathrm{~mL}$ of $5.25 \% \mathrm{NaOCl}$ to remove the debris in suspension, followed by $1.0 \mathrm{~mL}$ of $17 \%$ EDTA activated for $60 \mathrm{~s}$ to remove the smear layer. After that, the canal was rinsed with $1.0 \mathrm{~mL}$ of $5.25 \% \mathrm{NaOCl}$ to neutralize the EDTA solution. Finally, $1.0 \mathrm{~mL}$ of $5.25 \%$ $\mathrm{NaOCl}$ was activated for additional $60 \mathrm{~s}$, followed by rinsing with $1.0 \mathrm{~mL}$ of $5.25 \% \mathrm{NaOCl}$ to remove the debris in suspension (completing a total volume of

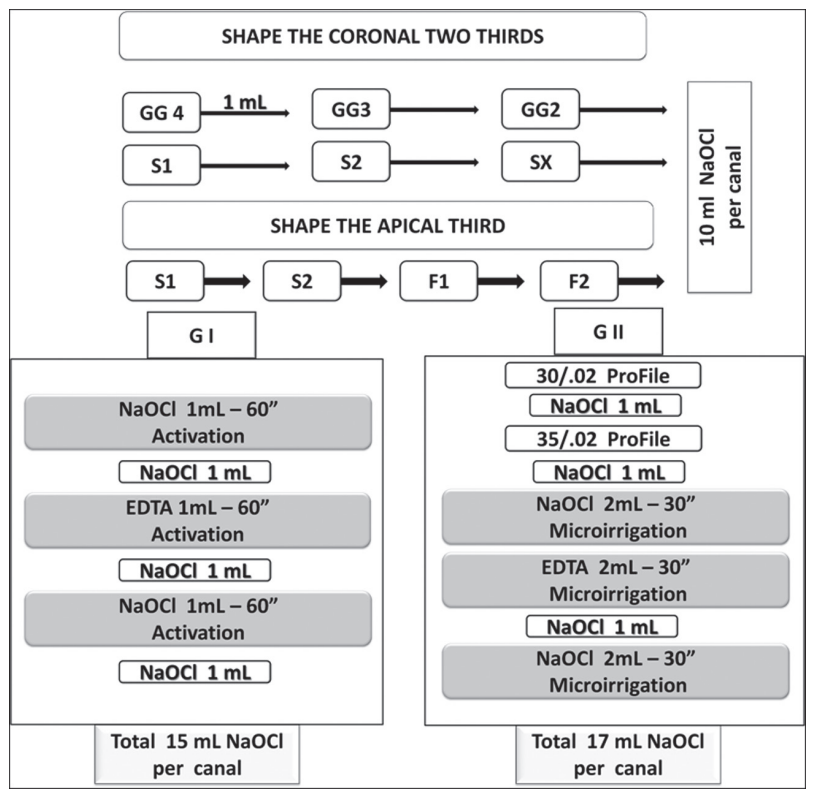

Figure 1. Diagram illustrating the procedures employed to shape the coronal and apical third. 
$15 \mathrm{~mL}$ of $\mathrm{NaOCl}$ per canal). Group 2: In the vacuum irrigation protocol, the EndoVac (Discus Dental, Culver City, CA, USA) master delivery tip was placed above the access opening to constantly deliver $5.25 \% \mathrm{NaOCl}$. Between each rotary instrument action, $1.0 \mathrm{~mL}$ of $\mathrm{NaOCl}$ per canal was used to replenish the irrigant in the pulp chamber and was aspirated by the macrocannula. This cannula is a plastic device with an open end that measures International Standards Organization (ISO) size 55 with a 002 taper. After instrumentation using the F2 PTU instrument, the canal shape was complemented with 30 and 35/.02 ProFile files to allow the microcannula to reach the WL, as indicated by Nielsen and Baumgartner (13). The microcannula is stainless steel and has 12 small, laterally positioned offset holes in 4 rows with 3 holes per row. It possesses a closed end measuring ISO size 32. Three cycles of microirrigation followed and during each cycle the canal and pulp chamber were maintained full of irrigant while the microcannula was placed at the WL for $6 \mathrm{~s}$, then lifted $2 \mathrm{~mm}$ coronally for $6 \mathrm{~s}$, and then moved back to the WL for $6 \mathrm{~s}$. This up-and-down motion continued for $30 \mathrm{~s}$, ensuring $18 \mathrm{~s}$ of active irrigation directly at the WL. Two milliliters of $5.25 \% \mathrm{NaOCl}$ were employed in the first cycle. The second microirrigation cycle used $2 \mathrm{~mL}$ of $17 \%$ EDTA during $30 \mathrm{~s}$ and was followed by rinsing with $1.0 \mathrm{~mL}$ of $5.25 \% \mathrm{NaOCl}$ to neutralize the EDTA. The third cycle again employed $2 \mathrm{~mL}$ of $5.25 \% \mathrm{NaOCl}$, completing a total volume of $17 \mathrm{~mL}$ per canal. Upon finishing canal preparation in both groups, a final irrigation with $1.0 \mathrm{~mL}$ of saline solution per canal was performed to remove the $\mathrm{NaOCl}$ residues and the canals were subsequently dried with paper points. All procedures were recorded using the dental-operating microscope (DF Vasconcelos, M900, São Paulo, Brazil).

The teeth had their mesial roots split into two halves using a metallic sheet. One half of each root was coded and images of the root halves were taken using a stereomicroscope with a digital camera (Carl Zeiss, KL 200, Göttingen, Germany) at $\times 10$ magnification. Image Pro-Express software was used to assess the

Table 1. Mean values and standard deviations of radius and angle of curvature of the root canals in each group.

\begin{tabular}{lcc}
\hline Variable & $\begin{array}{c}\text { Group 1 } \\
\text { (EndoActivator) }\end{array}$ & $\begin{array}{c}\text { Group 2 } \\
\text { (EndoVac) }\end{array}$ \\
\hline Mean radius $(\mathrm{mm})$ & $5.3 \pm 2.1$ & $5.5 \pm 2.2$ \\
Mean angle $\left(^{\circ}\right)$ & $23 \pm 10$ & $24 \pm 15$ \\
\hline
\end{tabular}

canal length in the optical photomicrographs and the same images and software were employed to define the apical thirds and the region until $2.0 \mathrm{~mm}$ from the WL. The images were randomly presented to three examiners (endodontic postgraduates) previously calibrated with images obtained in a pilot study, and were assessed in the following sequence: (a) Day 1: Calibration session (with 10 images from the pilot study); (b) Day 1: First randomized images session (with another set of 20 different images); (c) Day 10: Second randomized images session (with the same 20 images from day 1 but in a different sequence).

The three examiners were blinded with respect to the samples being scored and the agreement between the examiners was indicated by the Kappa test (21). The images of the root canals $(n=60)$ were scored according to the following semi-quantitative rate system: 1 . Small presence of debris (tiny white points drawing a trace of debris on the canal walls); 2 . Moderate presence of debris (small white points on the canal walls); and 3. Dense presence of debris (bigger white points on the canal walls, forming clusters).

The higher the score, the larger the amount of debris, that is, score 1 represented the cleanest root canals, score 2 represented a medium level of cleanliness, and score 3 referred to a greater amount of remaining debris and thus the worst level of cleanliness. Selected root halves with canal walls that were representative of each of the three scores described above were also observed in a scanning electron microscope (JSM $6360 \mathrm{LV}$; JEOL, Tokyo, Japan). The aim was to visualize with a higher resolution the characteristics of the root canal walls after using each irrigation procedure. Differences in the anatomic factors length, radius and angle of curvature between the groups were analyzed by one-way ANOVA, and debris removal among the two groups was analyzed by the Kruskal-Wallis equality of populations rank test at a significance level of 5\%. This analysis, as other non-parametric tests, uses the ranks

Table 2. Score distribution in each group.

\begin{tabular}{lccc}
\hline Score & $\begin{array}{c}\text { Group 1 } \\
\text { (EndoActivator) }\end{array}$ & $\begin{array}{c}\text { Group 2 } \\
\text { (EndoVac) }\end{array}$ & Total \\
\hline 1 & 25 & 12 & 37 \\
2 & 3 & 10 & 13 \\
3 & 2 & 8 & 10 \\
Root canal total (n) & 30 & 30 & 60 \\
\hline
\end{tabular}


of the data rather than their raw values to calculate the statistic data.

\section{RESULTS}

The mean values of canal length, radius and angle of curvature, which characterize the geometry of the curved root canals, are listed in Table 1. One-way ANOVA showed no significant difference $(p>0.05)$ in root canal length and geometry among the groups. Concerning the evaluation of the cleanliness of the dentine walls, the Kappa value of agreement among evaluators was 0.92 . Therefore, the scoring of the samples, which is shown in Table 2, was considered to be reliable. Statistical analysis by the Kruskal-Wallis test showed that at the whole apical third the root halves from Group 1 had significantly less surface debris $(p=0.002)$ than Group 2. In this test, the average score sums of the remaining debris after the preparations of root canals for the two experimental groups were 39.0 for Group 1 and 57.7 for Group 2. The teeth in which the vacuum protocol was applied showed better debridement until $2 \mathrm{~mm}$ from the WL in approximately $75 \%$ of the analyzed root canals. Characteristic images under the optical microscope of root canals scored as 1,2, and 3, are shown in Figure 2. Similar images with a higher magnification, obtained by means of scanning electron microscopy, are shown in Figure 3. It can be observed that canals scored 1 generally presented a regular pattern of open dentinal tubules with a small presence of smear layer; score 2 canals showed some open dentinal tubules and others covered by the smear layer; while in score 3 specimens the canal walls were entirely covered by a thick coating of smear layer without revealing any open dentinal tubules.

\section{DISCUSSION}

Irrigation of the root canal space is a fundamental aspect of root canal treatment. The efficacy of irrigation depends on how effectively it can bring the irrigant in contact with the materials and debris within the RCS in an attempt to remove these debris (22).

The penetration of the irrigant within the apical third of root canals depends on their complex anatomy. This region possesses a variety of ramifications, deltas and isthmuses besides different permeability. The irregularity of the dentin structure at the apical region has been shown in a study related to dentin permeability of the apical third (5). The presence of sclerotic dentin in all root canal walls of the apical third and between the dentinal tubules, probably caused by aggressions
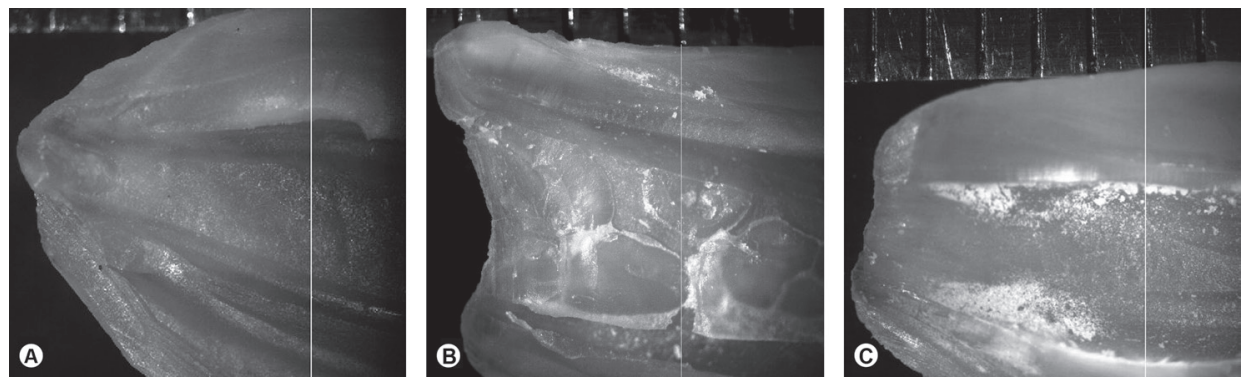

Figure 2. Stereomicroscopy images (original magnification of $\times 10$ ) of representative specimens of score 1: small presence of debris (A); score 2: moderate presence of debris (B); and score 3: dense presence of debris (C).
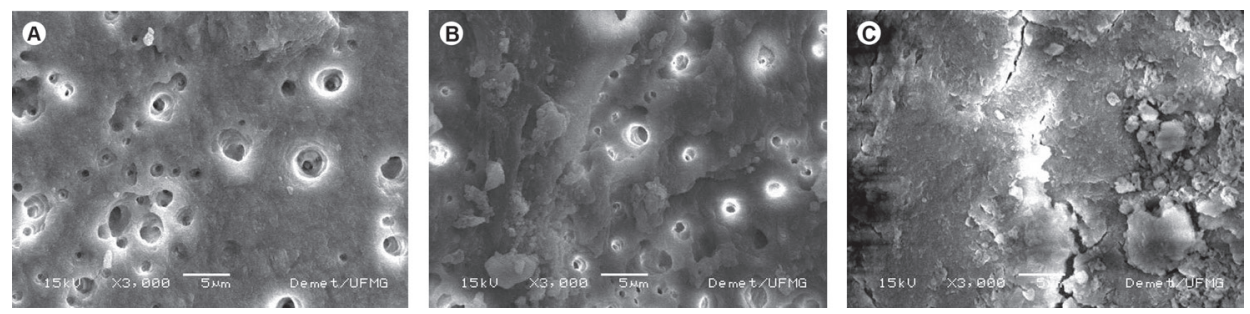

Figure 3. Scanning electron microscopy images (original magnification of $\times 3000$ ) of representative specimens of score 1 (A), score 2 (B) and score $3(\mathrm{C})$. 
such as caries, attrition, abrasion, occlusal trauma, among others, contributes to the formation of translucent or sclerotic dentin especially in the apical third. All those characteristics, as well as the apical taper and diameter, contribute to the complexity of the apical region $(5,13,18,20)$.

In this research the intent was to analyze different irrigation protocols in accordance with the manufacturer's recommendations $(6,13)$. No significant difference in length, radius and angle of curvature could be found among the teeth (Table 1) and thus the influence of anatomical factors on the capacity of debris removal was avoided.

As reported in Table 2, the scores can be translated into average cleanliness or percentage of debris removal. Thus, in relation to score 1, it can be observed that the sonic protocol (Group 1) produced cleanliness in 83\% of the cases and the vacuum protocol (Group 2) led to an average cleanliness of $40 \%$. During sonic activation, vigorous fluid agitation was observed within the pulp chamber. Vibrating the tip, in combination with moving the tip up and down in short vertical strokes, synergistically produced a hydrodynamic phenomenon, which could be the reason for the efficient performance of the sonic protocol in this study. As reported in earlier studies, the sonic irrigation promotes irrigant penetration within simulated lateral canals (7), with a minor amount of irrigant extruded to the apex (16). In addition, it is very practical to use. However, Jiang et al. (7) reported that the oscillation range of the sonic device tips was $1.2 \pm 0.1 \mathrm{~mm}$, resulting in a great deal of wall contact and no cavitation of the irrigant.

In the work of Boutsioukis et al. (11), the irrigant positive flow was simulated with the microcannula and the most intense jets were formed through the most proximal holes, which were responsible for $73 \%$ of the total flow. Although in the present work the microcannula was used to aspirate the irrigant, the greatest amount of debris removal from the WL up to $2 \mathrm{~mm}$ of this length on the root apical canals is possibly the result of the microcannula design, concentrating the turbulence at this region besides the up and down motion of this cannula during the microirrigation cycles. These characteristics of design and turbulence are probably the reason for the better cleaning of the apical $2 \mathrm{~mm}$. The cleanliness in the apical region is of great importance as this is the area with the highest anatomic complexity, beyond which irrigation becomes difficult. Similar results were found by Nielsen and Baumgartner (13), who observed significantly less remaining debris at $1.0 \mathrm{~mm}$ from the WL for the vacuum irrigation as compared to conventional irrigation. However, these authors did not find a statistically significant difference of debris removal at the $3.0 \mathrm{~mm}$ level. Although the safety of the methods was not analyzed here, one advantage of the EndoVac is its ability to safely deliver irrigant to the WL without irrigant extrusion to the periradicular tissues $(2,23,24)$. Both characteristics of the vacuum irrigation, effective cleanliness at the extension of $2.0 \mathrm{~mm}$ from the WL and its security concerning irrigant extrusion, make the Group 2 protocol valuable on clinical trials.

In a similar research previously conducted (25), none of the irrigant agitation protocols completely removed debris and smear layer from flattened root canals as in this study. Nevertheless, those authors compared machine-assisted agitation systems (ultrasound and EndoVac) with the manual techniques and found that machined systems removed more debris than the manual techniques.

In conclusion, the present in vitro study, in which sonic and vacuum irrigation protocols were employed according to the manufacturers' instructions, revealed that the sonic protocol left behind less debris considering the whole apical third than did the vacuum protocol. However, at $2 \mathrm{~mm}$ from the WL the vacuum protocol had a better performance in debris removal. Nonetheless, neither of the irrigation protocols evaluated in this study was capable of completely removing the debris from the RCS.

\section{RESUMO}

Este estudo avaliou protocolos de irrigação sônica e a vácuo em relação à capacidade de remoção de debris do sistema de canais radiculares. Trinta primeiros molares mandibulares tiveram seus canais radiculares preparados pela utilização do Sistema ProTaper Universal. Os dentes foram divididos em dois grupos experimentais $(n=15)$ : Grupo 1: protocolo de irrigação sônica, e Grupo 2: protocolo de irrigação a vácuo. Posteriormente, as raízes mesiais foram seccionadas e observadas em lupa estereoscópica e microscopia eletrônica de varredura. Três examinadores independentes avaliaram as imagens do terço apical de acordo com as seguintes pontuações: 1. pequena presença de debris; 2: moderada presença de debris; e 3. densa presença de debris. Os dados foram analisados pelos testes estatísticos ANOVA e Kruskal-Wallis $(\alpha=0,05)$. A comparação entre os grupos revelou que, no terço apical, as hemissecções radiculares do Grupo 1 apresentaram debris remanescentes de forma significativamente menor $(\mathrm{p}=0,002)$ do que as do Grupo 2 . No entanto, a $2 \mathrm{~mm}$ do comprimento de trabalho, as amostras do Grupo 2 mostraram menos debris remanescentes em aproximadamente $75 \%$ dos canais radiculares analisados. Considerando todo o terço apical, 
o protocolo de irrigação sônica removeu significativamente mais debris do que o protocolo de irrigação a vácuo. No entanto, na região a $2 \mathrm{~mm}$ do comprimento de trabalho, o segundo método de irrigação demonstrou um melhor desempenho.

\section{REFERENCES}

1. Violich DR, Chandler NP. The smear layer in endodontics - a review. Int Endod J 2010;43:2-15.

2. Gregorio C, Estevez R, Cisneros R, Paranjpe A, Cohenca N. Efficacy of different irrigation and activation systems on the penetration of sodium hypochlorite into simulated lateral canals and up to working length: an in vitro study. J Endod 2010;36:12161221.

3. Van der Sluis LWM, Gambarini G, Wu MK, Wesselink PR. The influence of volume, type of irrigant and flushing method on removing artificially placed dentine debris from the apical root canal during passive ultrasonic irrigation. Int Endod J 2006;39:472-476.

4. Hülsmann M, Heckendorff $M$, Lennon A. Chelating agents in root canal treatment: mode of action and indications for their use. Int Endod J 2003;36:810-830.

5. Ribeiro RG, Marchesan MA, Silva RG, Sousa-Neto MD, Pécora JD. Dentin permeability of the apical third in different groups of teeth. Braz Dent J 2010;21:216-219.

6. Ruddle CJ. Hydrodynamic disinfection tsunami endodontics. Dent Today 2007;26:1-9.

7. Jiang LM, Verhaagen B, Versluis M, Van Der Sluis LWM. Evaluation of a sonic device designed to activate irrigant in the root canal. J Endod 2010;36:143-146.

8. Baugh D, Wallace J. The role of apical instrumentation in root canal treatment: a review of the literature. J Endod 2005;31:333340.

9. Lee SJ, Wu MK, Wesselink PR. The effectiveness of syringe irrigation and ultrasonics to remove debris from simulated irregularities within prepared root canal walls. Int Endod J 2004;37:672-678.

10. Al Jadaa A, Paqué F, Attin T, Zehnder M. Necrotic pulp tissue dissolution by passive ultrasonic irrigation in simulated accessory canals: impact of canal location and angulation. Int Endod J 2009;42:59-65.

11. Boutsioukis C, Verhaagen B, Versluis M, Kastrinakis E, Wesselink PR, Van Der Sluis LWM. Evaluation of irrigant flow in the root canal using different needle types by an unsteady computational fluid dynamics model. J Endod 2010;36,875-879.
12. Dutner J, Mines P, Anderson A. Irrigation trends among American Association of Endodontists members: a web-based survey. J Endod 2012,38:37-40.

13. Nielsen BA, Baumgartner JC. Comparison of the EndoVac system to needle irrigation of root canals. J Endod 2007;33:611-615.

14. Lussi A, Nussbächer U, Grosrey J. A novel noninstrumented technique for cleansing the root canal system. J Endod 1993; 19:549-553.

15. Lussi A, Suter B, Fritzche A, Gygax M, Portman P. In vivo performance of a new non-instrumentation technology (NIT) for root canal obturation. Int Endod J 2002;35:352-358.

16. Gu L, Kim JR, Ling J, Choi KK, Pashley DH, Tay FR. Review of contemporary irrigant agitation techniques and devices. J Endod 2009;35:791-804.

17. Bhuva B, Patel S, Wilson R, Niazi S, Beighton D, Mannocci F. The effectiveness of passive ultrasonic irrigation on intraradicular Enterococcus faecalis biofilms in extracted single-rooted human teeth. Int Endod J 2010;43:241-250.

18. Huang TY, Gulabivala K, Ng YL. A bio-molecular film ex-vivo model to evaluate the influence of canal dimensions and irrigation variables on the efficacy of irrigation. Int Endod J 2008;41:60-71.

19. Pruett JP, Clement DJ, Carnes Jr DL. Cyclic fatigue testing of nickel-titanium endodontic instruments. J Endod 1997;23:77-85.

20. Ruddle CJ. The ProTaper technique. Shaping the future of endodontics. In: Castellucci A, ed. Endodontics, vol II. Florence: II Tridente; 2005. p. 548-563.

21. Landis JR, Koch GG. The measurement of observer agreement for categorical data. Biomet 1977;33:159-174.

22. Nguy D, Sedgley C. The influence of canal curvature on the mechanical efficacy of root canal irrigation in vitro using real-time imaging of bioluminescent bacteria. J Endod 2006;32:1077-1080.

23. Desai P, Himel V. Comparative safety of various intracanal irrigation systems. J Endod 2009;35:545-549.

24. Mitchell RP, Baumgartner JC, Sedgley CM. Apical extrusion of sodium hypochlorite using different root canal irrigation systems. J Endod 2011;37:1677-1681.

25. Ribeiro EM, Silva-Sousa YT, Souza-Gabriel AE, Sousa-Neto MD, Lorencetti KT, Silva SR. Debris and smear removal in flattened root canals after use of different irrigant agitation protocols. Microsc Res Tech 2012;75:781-790.

Received March 3, 2012 Accepted August 15, 2012 